\title{
Description of the third instar larva of Megadytes latus (Fabricius) (Coleoptera, Dytiscidae), with an identification key for described larvae of the genus
}

\author{
Nelson Ferreira-Jr; Livia B. Nicolini \& Jorge L. Nessimian \\ Laboratório de Entomologia, Departamento de Zoologia, Instituto de Biologia, Universidade Federal do Rio de Janeiro. \\ Caixa Postal 68044, 21944-970 Rio de Janeiro, Rio de Janeiro, Brasil. E-mail to: nferrejr@acd.ufrj.br
}

\begin{abstract}
The last instar larva of M. latus (Fabricius, 1801) is described and figured, based on reared specimens from Serra dos Órgãos, Teresópolis, state of Rio de Janeiro, Brazil. Some notes on the biotope are provided. KEY WORDS. Atlantic Forest; Brazil; Neotropical Region; taxonomy.
\end{abstract}

\begin{abstract}
RESUMO. Descrição da larva de terceiro ínstar de Megadytes latus (Fabricius) (Coleoptera, Dytiscidae). A larva de terceiro ínstar de M. latus (Fabricius, 1801) é descrita e ilustrada, baseado em espécimes criados da Serra dos Órgãos, Teresópolis, Rio de Janeiro, Brasil. Algumas notas acerca do biótopo onde as larvas foram coletadas são incluídas.
\end{abstract}

PALAVRAS-CHAVE. Brasil; Mata Atlântica; Região Neotropical; taxonomia.

The genus Megadytes Sharp, 1882 is widely distributed on the Neotropics. Currently, this genus includes 22 species, 14 of which are reported from Brazil (BLACKWELDER 1944, Mouchamps 1957, Tremouilles \& Bachmann 1980, Tremouilles 1989, Ferreira-JR 2000). Most species are frequently associated with lentic habitat, where a large number of larvae may be found. Although Megadytes larvae are common, only the larvae of $M$. australis (Germain, 1854) (CekAlovic 1974), M. giganteus (Laporte, 1834) (Ferreira-Jr 1993, 2000), M. glaucus (Brulle, 1836) (Crespo 1982), M. fallax (Aubé, 1838) and M. marginithorax (Perty, 1830) (FerReirAJR 1995) have been described.

Megadytes latus (Fabricius, 1801) has been reported from Argentina, Brazil, French Guiana and Uruguay (SHARP 1882, BLACKWelder 1944, Mouchamps 1957, Tremouilles \& BaChManN 1980, TREMOUILLES 1989). In the present study identification of the larvae was based on an adult specimen obtained from reared larvae. The larvae were collected in a stream called Rio da Varginha, in Teresópolis, Rio de Janeiro state, Brazil. The larvae were reared in laboratory, in styrofoam boxes and fed with tadpoles, small fishes and larvae of other insects. The examined material was deposited in the Entomological Collections of the Departamento de Zoologia (DZRJ), Instituto de Biologia, Universidade Federal do Rio de Janeiro.

Description (Figs 1-4). Total length $54.00 \mathrm{~mm}$; length of head $5.00 \mathrm{~mm}$; maximum width of head $3.80 \mathrm{~mm}$; length of pronotum $5.20 \mathrm{~mm}$; maximum width of pronotum $4.80 \mathrm{~mm}$; length of abdominal segment VII $4.16 \mathrm{~mm}$; length of abdominal segment VIII $6.80 \mathrm{~mm}$.

Larva elongated, typical of Cybistrini. Dorsum ochraceous, with one median and two lateral narrow yellow- ish bands extending from mesonotum to abdominal segment VI; abdominal segment VII with a median dark band; venter yellowish. Head with distinct pattern.

Head subquadrate, longer than wide, neck region narrow covered by thorax. Dorsal region with ecdysial cleavage line $\mathrm{Y}$ shaped. Clypeus trilobed; median lobe conic, truncated, with apical tuft of setae; lateral lobe pronouced, lesser than medium lobe, closer to median lobe than antero-lateral angle, with apical tuft of setae and some setae throughout its external margin. Ocular area with four dorsal and two ventral ocelli in two transverse rows of three ocelli each, posteriorly delimited by a row of setae. Venter marked by the ecdysial cleavage line.

Antennae 9-segmented, long, slender; penultimate segment with accessory sensorial appendage articulated apically. Mandibles long, stout, falciform, with transverse crown of setae at apex and with dorsal pubescence. Maxillary stipes long, slender. Palpifer long, slender. Maxillary palpi 8-segmented, long, slender. Premaxillary lobe present, without subconic tegumentary process; spinulose area with tuft of spiniform setae. Labium with broad, rectangular, membranous mentum; prementum membranous medially, sclerotized laterally, with small ligula; labial palpi 4-segmented.

Pronotum sclerotized, long, narrowed anteriorly, subequal in length to meso- and metanotum together. Prosternal process triangular. Anterior half of meso- and metanotum each with sclerotized plate, posterior half membranous; plates narrowed anteriorly and with transversal carine. Meso- and metathorax with one pair of spiracles in pleural region each, beneath antero-lateral angles of tergite.

Legs sclerotized, elongate, subcylindrical, 5-segmented,

Revista Brasileira de Zoologia 23 (3): 792-795, setembro 2006 

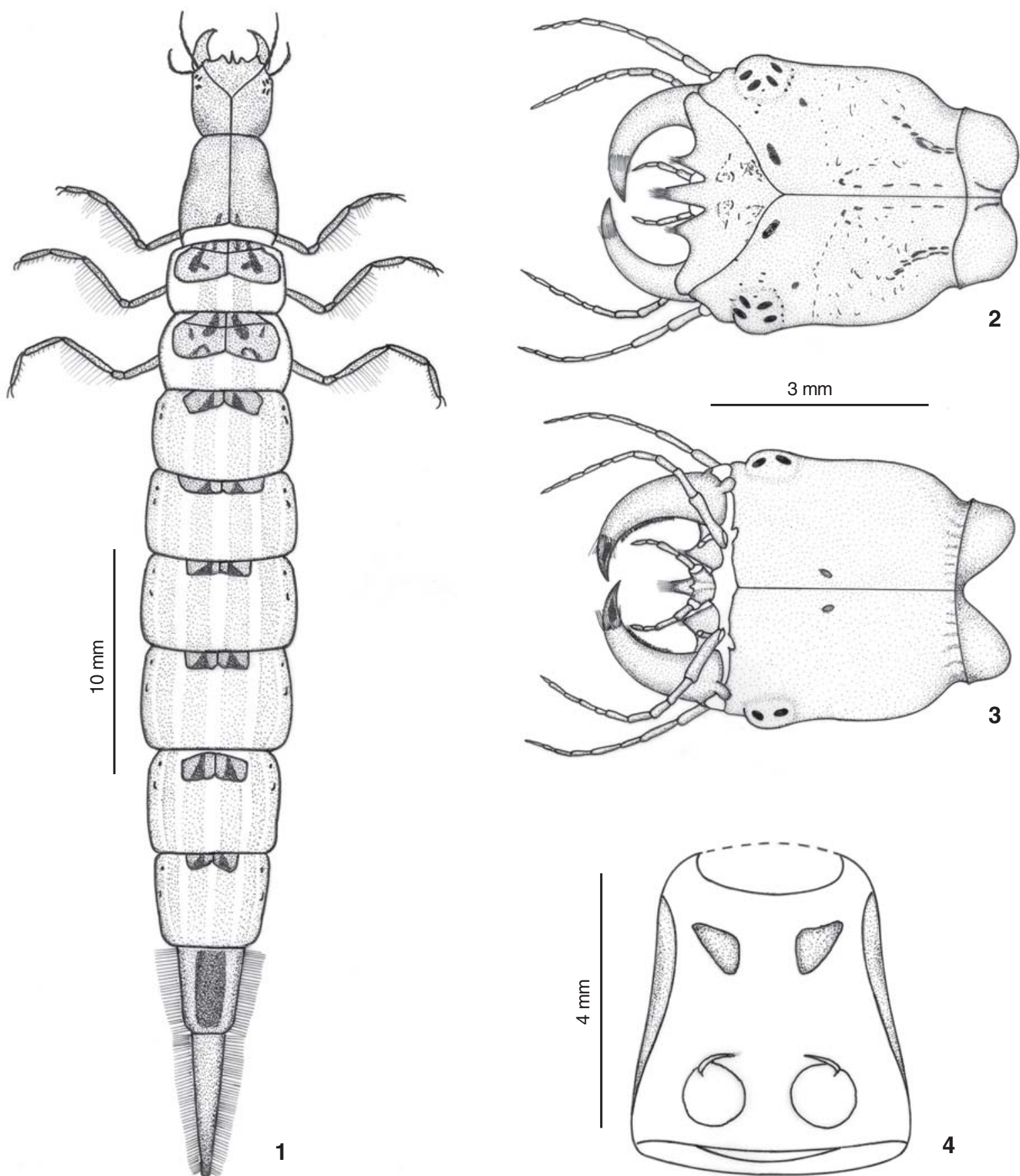

2

Figures 1-4. Megadytes latus, last instar larva: (1) larva, dorsal view; (2) head dorsal view; (3) head ventral view; (4) prothorax, ventral view.

each with a fringe of swimming setae extending from posterodorsal face of femora to tarsi; first pair with a fringe of setae extending from ventral face of trochanter to tibia and with row of spiniform setae in tarsi; second and third pairs with a fringe of setae extending from ventral face of trochanter to femora and with row of spiniform setae in tibia and tarsi, claws simple, subequal in length.

Abdomen elongate, with eight segments, segments I to VI, cylindrical, membranous, with small antero-dorsal sclerites; each segment with a small mid-lateral sclerite and a pair

Revista Brasileira de Zoologia 23 (3): 792-795, setembro 2006 
of antero-lateral spiracles; segment VII sclerotized, with a narrow, longitudinal, ventral membranous area inside which is a pair of antero-lateral spiracles; segment VIII conic, completely sclerotized, with a pair of apical spiracles, segments VII and VIII bearing lateral longitudinal fringe of swimming setae. Cerci minute, ventrally placed at apex of last segment.

Specimens examined. BraziL, Rio de Janeiro: Teresópolis (Serra dos Órgãos, Rio da Varginha, $22^{\circ} 27^{\prime} 45^{\prime \prime}$ S, 42 $53^{\circ} 27^{\prime \prime} W$ ), 30-31-III-1996, Equipe Entomológica leg., two last instar larvae, one reared to adult.

Biological notes. Larvae and adults were collected in Rio da Varginha and its tributaries, in an atlantic forest area at c.a. 1,000 m of altitude, Serra dos Órgãos, Teresópolis. The larvae dwell in litter deposits, roots of hydrophytes and terrestrial vegetation on dam margins or low current stream sections. The larvae show little activity and stays hidden waiting for prey.

Discussion. Since created by SHARP (1882) the conspicuous morphology of Cybistrini has been demonstrated by various authors (Chatanay 1911, Balfour-Browne 1934, Galewski 1973, Bertrand 1977). Indeed, Ferreira-Jr (2000) has presented some exclusive larval characteristics that indicate the monophyletic condition of the tribe. However, the relationship of Cybistrini with other groups of Dytiscinae has only been studied in a cladistics context by Miller $(2000,2001)$. In his study Miller found Cybistrini to be a sister group to the other Dytiscinae. This result is contrary to the idea that Cybistrini assumes a derived position in the family, as proposed by NiLsson (1988) using larval chaetotaxy.

The tribe presents about 135 species, with most species occurring in the tropics (NiLsson \& Holmen 1995). Of this tribe, about 100 species of the genus Cybister Curtis, 1827 occurs mainly in the Old World, with few species in North and South America. Nine species of the genera Austrodytes Watts, 1978, Onychohydrus Schaum \& White, 1847 and Spencerhydrus Sharp, 1882 are found in the Australian region, and the only species of the genus Regimbartina Chatanay, 1911 is Afrotropical. The 22 species of Megadytes are exclusively Neotropical.

Although it is relatively large, the knowledge of the immature form in species of this tribe is meager. As mentioned by Bertrand (1977) and FerReira-Jr (1993, 1995, 2000), the current knowledge of Megadytes larvae is not enough to distinguish them morphologically from those of Cybister. More so, in a study comparing external morphology of larvae of different genera in Cybistrini, FerReIRA-JR (2000) found that some of the variations found between the species of Megadytes are also found in the larvae of different sorts of Cybistrini. Therefore with the current knowledge of Cybistrini larvae it is not possible to support the monophyletic status of Megadytes nor of its subgenera. The geographic distribution criterion, used by BERTRAND (1977), still is the best one to identify Cybistrini larvae.

The larvae of M. latus are distinguished from other larvae of Megadytes by the following characters combined: head longer than wide; clypeal median lobe conic, truncated, with apical tuft of setae; lateral lobe single and pronounced, closer to median lobe than antero-lateral angle, with apical tuft of setae and some setae throughout its external margin; without subconic tegumentary process; ligula small; prosternal process triangular; sclerite of abdominal segment I with a transverse carina.

\section{Identification key for described larvae of Megadytes}

1. Head subrectangular, clearly longer than wide; clypeal lateral lobe separated from median lobe by narrow and deep cleft M. marginithorax

1 '. Head subquadrate; clypeal lateral lobe separated from median lobe by wide cleft ...... 2

2. Clypeal median lobe broad at base, abruptly pointed apically, without apical tuft of setae; clypeal lateral lobe closer anterolateral lobe than median lobe .............................. M. fallax

2 '. Clypeal median lobe conic, truncate apically, with apical tuft of seta; clypeal lateral lobe closer median lobe than antero-lateral lobe .. 3

3. Clypeal lateral lobe pointed .................................................... 4

3'. Clypeal lateral lobe bifid .................................................. 5

4. Head as long as wide; clypeal lateral lobe obtuse M. giganteus

4 '. Head slightly longer than wide, clypeal lateral lobe acute M. latus

5. Internal lobe of clypeal lateral lobe longer than external lobe; mandible with subapically transverse row of setae M. glaucus

5 '. Internal lobe of clypeal lateral lobe so long as external lobe; mandible without subapically transverse row of setae ..... M. australis

\section{ACKNOWLEDGMENTS}

To Alcimar do L. Carvalho (Museu Nacional, UFRJ) and Renata Schama (Instituto de Biologia, UFRJ) for providing useful suggestions on the manuscript.

\section{REFERENCES}

Balfour-Browne, F. 1934. The proventriculus in the Dytiscidae (Col.) as a Taxonimic character. Stylops, London, 3: 241-244.

Bertrand, H.P.I. 1977. Larves et nymphes des coléoptères aquatiques du globe. Paris, Centre National de la Recherche Scientifique, VI+804p.

BLACKWELDER, R.E. 1944. Checklist of the coleopterous insects of Mexico, Central America, the West Indies and South America. Bulletin of the United States National Museum, Washington, 185 (1): XII+1-188.

Cekalovic, T.K. 1974. Descripción de la larva de Megadytes australis (Germain), 1854 (Coleoptera, Dytiscidae). Boletin de da Sociedad de Biologia de Concepción, Concepción, 48: 33-40.

Chatanay, J. 1911. Sur le tarse des dytiscides. Essai de morphologie comparée. Annales de la Société Entomologique de France, 
Paris, 79: 395-466.

Crespo, F.A. 1982. Megadytes (Paramegadytes) glaucus (Brulle), descripcion del tercer estadio larval y de la pupa (Dytiscidae, Coleoptera). Physis, Buenos Aires, Secc. B, 41 (100): 7-13.

Ferreira-JR, N. 1993. Descrição da larva de Megadytes giganteus (Castelnau, 1834) com notas biológicas (Coleoptera: Dytiscidae). Revista Brasileira de Entomologia, São Paulo, 37 (1): 57-60.

FerReira-JR, N. 1995. Description of the larvae of Megadytes fallax (Aubé) and M. marginithorax (Perty) (Coleoptera: Dytiscidae). The Coleopterists Bulletin, Natchez, 49 (4): 313-318.

Ferreira-JR, N. 2000. Morfologia externa da larva de Megadytes giganteus (Laporte, 1834) (Coleoptera: Dytiscidae) e evidências sobre a condição monofilética da tribo Cybistrini. Revista Brasileira de Entomologia, São Paulo, 44 (1/2): 57-69.

GalewsKI, K. 1973. Generic characters of the larvae of the subfamily Dytiscinae (Dytiscidae) with a key to the central European genera. Polskie Pismo Entomologiczne, Warszawa, 43 (3): 491-498.

MilleR, K.B. 2000. Cladistic analysis of the tribes of Dytiscinae and the phylogenetic position of the genus Notaticus Zimmermann (Coleoptera; Dytiscidae). Insect Systematics and Evolution, Stenstrup, 31: 165-177.

MiLLER, K.B. 2001. On the phylogeny of the Dytiscidae (Coleop- tera) with emphasis on the morphology of the female reproductive tract. Insect Systematics and Evolution, Stenstrup, 32: 45-92.

Mouchamps, R. 1957. Contribution à la connaissance des Cybisterini (Col. Dytiscidae) des Musée d’Histoire Naturelle de Vienne. Annalen des Naturhistorischen Museums in Wien, Wien, 61: 278-287.

Nitsson, A.N. 1988. A review of primary setae and pores on legs of larval Dytiscidae (Coleoptera). Canadian Journal of Zoology, Ottawa, 66 (10): 2283-2294.

Nilsson, A.N. \& M. Holmen. 1995. The aquatic adephaga (Coleoptera) of Fennoscandia and Denmark. II. Dytiscidae. Leiden, Fauna Entomologica Scandinavica, vol. 32, 192p.

SHARP, D. 1882. On aquatic carnivorous Coleoptera or Dytiscidae. Scientific Transactions of the Royal Dublin Society, Dublin, 2 (2): 179-1003.

Tremouilles, E.R. 1989. Notas sobre Coleoptera acuaticos Neotropicales. III. Datos ampliatorios sobre distribuicion geografica de especies de Megadytes Sharp (Coleoptera, Dytiscidae). Revista de la Sociedad Entomologica Argentina Buenos Aires, 45 (1-4): 159-161.

Tremouilles, E.R. \& A.O. Bachmann. 1980. La tribu Cybisterini en la Argentina (Coleoptera, Dytiscidae). Revista de la Sociedad Entomologica Argentina, Buenos Aires, 39 (1-2): 101-125.

Received in 17.I.2006; accepted in 25.VIII.2006. 